\title{
More effective professional development can help 4-H volunteers address need for youth scientific literacy
}

by Martin H. Smith and Lynn Schmitt-McQuitty

Nonformal education programs like 4-H can help address the need to improve scientific literacy among $K-12$ youth in the United States. To accomplish this, however, it is imperative that adult volunteers who serve as 4-H science educators engage in effective professional development. Currently, most 4-H volunteers who lead science projects and activities with youth participate in professional development opportunities involving episodic workshops that are considered largely ineffective with regard to fostering meaningful change in educators' knowledge and skills. In contrast, professional development models that involve communities of practice (CoPs), whereby groups of educators work toward shared learning goals through authentic work, have been shown to be effective. Professional development models that utilize CoPs represent potential strategies to help meet the professional development needs of 4-H volunteers who implement science programming with youth. Further investigation of these models within the context of 4-H science is recommended.

M ost aspects of life in twenty-firstcentury society are impacted by science, and many political and economic decisions require that sound choices be made by a population that is scientifically literate (Miller 2006). Citizens of the United States need a fundamental understanding of scientific concepts and theories as well as the capacity to use scientific thinking to address important national and global challenges (Miller 2006). The way to accomplish this is through deliberate education efforts (Lappan 2000).

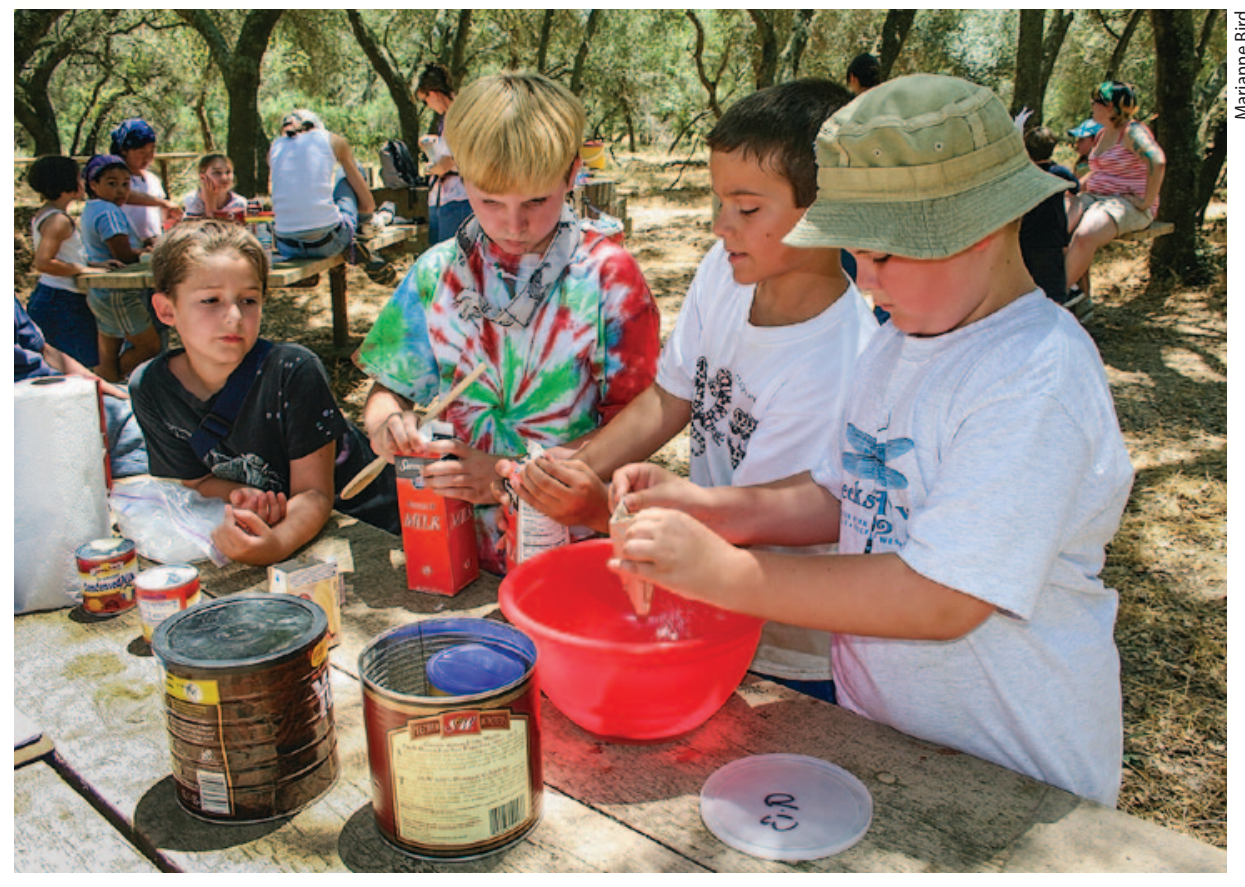

4-H programs emphasize hands-on inquiry and experiential learning, approaches known to be effective in increasing scientific literacy. Kitchen science activities provide opportunities to explore science in everyday life, as shown by these kids at the Sacramento County 4-H Day Camp.

Project 2061, launched in 1985 by the American Association for the Advancement of Science (AAAS), targeted the need for improved scientific literacy by establishing it as a goal for all schoolaged children (AAAS 1990) and specifying the most important knowledge and skills necessary for elementary, middle and high school students in its landmark publication Benchmarks for Science Literacy (AAAS 1993). Subsequently, the National Science Education Standards (National Research Council 1996) and state frameworks such as the California Science Content Standards for Public Schools (California State Board of Education 1998) were developed to help guide instructional content and pedagogical processes.

Despite state and national benchmarks and standards, however, assessments have shown poor science achievement among K-12 youth in the United States for many years (Grigg et al. 2006; NCES 2011). Additionally, results from international tests in science have revealed that U.S. students lag behind grade-level peers from other countries, which has prompted concerns about the future of the nation's economy and national security (National Research Council 2007). Furthermore, the low level of youth scientific literacy in California is particularly disconcerting. As a whole, California students scored below national averages on recent achievement tests (Grigg et al. 2006; NCES 2011). More specifically, males outperformed females, African Americans and Latinos performed significantly more poorly than whites and Asian Americans, and high-income youth outperformed lowincome youth, even though high-income youth as a group did not meet targeted national proficiency levels (Grigg et al. 2006; NCES 2011). Building a foundation in science through public school instruction has not been a priority in recent years in California (Bland et al. 2011; Smith and Trexler 2006), and this has weakened the delivery of science education in the state's classrooms.

Online: http://californiaagriculture.ucanr.edu/

landingpage.cfm?article=ca.v067n01p47\&fulltext=yes DOI: 10.3733/ca.v067n01p47 


\section{Scientific literacy and 4-H}

Although focusing on improvements in school-based instruction is one strategy to address the low levels of academic achievement in science among U.S. youth (Smith and Trexler 2006), education programs that occur during out-of-school hours are receiving increasingly more recognition as viable options for sparking youths' interest in science, improving scientific literacy and reinforcing classroom different parts of the country around the turn of the twentieth century (Enfield 2001). Youth participating in these early 4-H clubs gained real-world education related to agriculture through hands-on learning experiences (Enfield 2001). Today, $4-\mathrm{H}$ is considered to be one of the largest youth organizations in the world (USDA 2010).

Nearly $50 \%$ of all 4 -H members participate in hands-on science experiences

\section{... results from international tests in science have revealed that U.S. students lag behind grade-level peers from other countries ...}

learning by helping to expand curriculum offerings and complement formal instruction (Kahler and Valentine 2011; Mørch and du Bois-Reymond 2006). Falk and Dierking (2010) maintain that most science is learned outside the school setting and emphasize the importance of these educational experiences in developing scientific literacy. Additionally, recent work by Bell et al. (2009) calls attention to the role and value of community-based programs in providing science education experiences. Furthermore, Sullenger (2006) offers that out-of-school science education may be more effective in improving scientific literacy than science courses taught in schools.

The 4-H Youth Development Program, administered by land-grant universities in all 50 states, provides learning opportunities for young people aged 5 to 19 during out-of-school hours. The origins of 4-H can be traced to Boys and Girls Agricultural Clubs, which appeared in

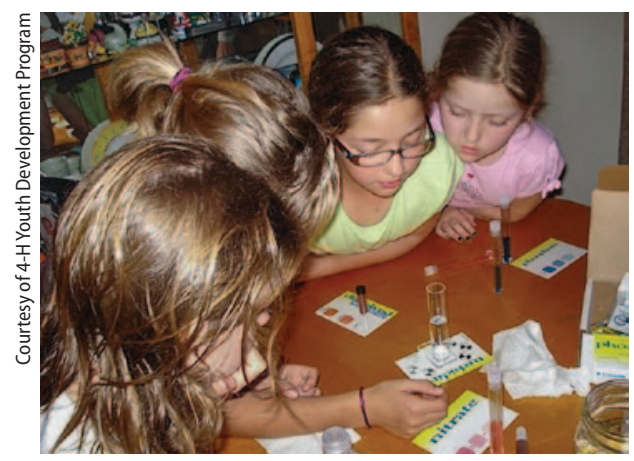

About half of all 4-H curricula are science related. 4-H youth in Orange County test water quality, checking for specific chemicals, turbidity and other factors. through county, state and national 4-H programs, projects and activities (USDA 2010). Although 4-H continues to provide educational opportunities for youth in the agricultural sciences, the scope of its curriculum offerings has been expanded to include a wide selection of program options in the biological, environmental, engineering and technological sciences. By providing science education programming in more content areas, $4-\mathrm{H}$ is able to reach a broader audience and address the needs and interests of youth from urban and suburban populations, as well as expand curriculum offerings to youth enrolled in after-school programs, summer camps and other shorter-term learning opportunities.

In 2007, National 4-H launched the 4- $\mathrm{H}$ Science Mission Mandate as its official response to the low levels of scientific literacy and workforce preparedness among youth in the United States (Garrett and Locklear 2007). Congruent with program priorities outlined by the National 4-H Science Mission Mandate, the California 4-H Youth Development Program developed the statewide 4-H Science, Engineering, and Technology (SET) Initiative in 2008 (Junge et al. 2009). The overarching goal of the California 4-H SET Initiative is to help advance scientific literacy among youth in the state through improved science programming, involving a variety of interrelated strategies: the development and implementation of curriculum materials that utilize inquiry and experiential learning, effective professional development of $4-\mathrm{H}$ staff and volunteers, the development of

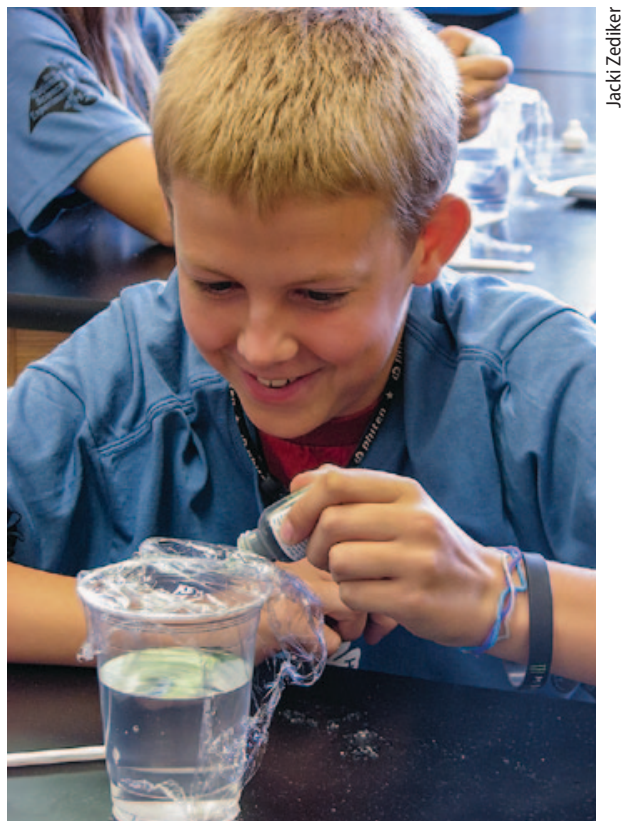

4-H volunteers would benefit from professional development opportunities of longer duration. At a 4-H National Youth Science Day activity in Siskiyou County, a 4-H member watches closely to see what will happen next.

new partnerships that help advance 4-H programming and reach new youth audiences, and expanded fund development to support 4-H SET programming.

The California 4-H SET Initiative also complements the University of California, Division of Agriculture and Natural Resources (UC ANR) Strategic Vision 2025 (Regents of UC 2009), a vision statement intended to help guide ANR research and extension programs through the early part of the twenty-first century. The goal of improved scientific literacy among California's population is specifically included as a major area of inquiry within the Healthy Families and Communities (HFC) Strategic Initiative, focusing on the investigation of the impacts of community-based education programs on science knowledge, process skills and attitudes toward science among K-12 youth in California and the impacts of professional development in science on the pedagogical and content knowledge and skills of science educators (Campbell et al. 2010). Furthermore, these research and extension priorities are congruent with the 4-H SET Initiative's Plan of Action, which targets improved youth science programming and effective professional development for science educators (Ambrose et al. 2011). 


\section{Educating the educators}

There are many factors that contribute to the low level of scientific literacy among school-aged youth in the United States, including instructional methods and professional development strategies for science educators. Most science is taught using methods that focus on the direct delivery of information (e.g., lectures and demonstrations), emphasizing the memorization of known facts (Jorgenson and Vanosdall 2002). Although some literature supports the use of these methods when teaching science (e.g., Schwerdt and Wuppermann 2011), strategies that focus on direct instruction do not provide learners with an in-depth understanding of science content and do little to contribute to their ability to use scientific thinking processes (Cole et al. 2002). Conversely, constructivistbased teaching strategies such as inquiry, which are learner centered and encourage knowledge discovery and the development of science-process skills, hold promise for improving scientific literacy. A recent synthesis of research on the impacts of inquiry-based science instruction on learner outcomes provided evidence of clear and consistent trends associated with improved learning of science among K-12 youth (Minner et al. 2010).

The perpetuation of didactic teaching methods in science is largely the result of the approaches to professional development used with science educators. In a national study, Garet et al. (2001) reported that the majority of participating science teachers engaged in what they defined as traditional professional development activities. These included workshops, conference presentations, institutes and courses, all of which can be characterized as episodic events that occur at a set time and location, with content delivered by someone external to the educators' learning setting, and lacking in sustained support (Garet et al. 2001). This type and design of educator professional development in science is broadly viewed as ineffective (Garet et al. 2001; LoucksHorsley et al. 2003; Penuel et al. 2007). Participating educators are passive recipients of knowledge, the strategies used typically do not model effective teaching practices, and the methods used do not foster meaningful change in the teachers' practices (Loucks-Horsley et al. 2003). Furthermore, such traditional approaches to educator professional development do not promote the advancement of educators as leaders, a critical factor necessary for long-term, sustainable educational change (Lambert et al. 2002).
In contrast, several researchers have summarized key features of effective professional development approaches in science (Garet et al. 2001; Guskey 2003; Guskey and Yoon 2009; Loucks-Horsley et al. 2003; Penuel et al. 2007; Supovitz and Turner 2000). Referred to by some

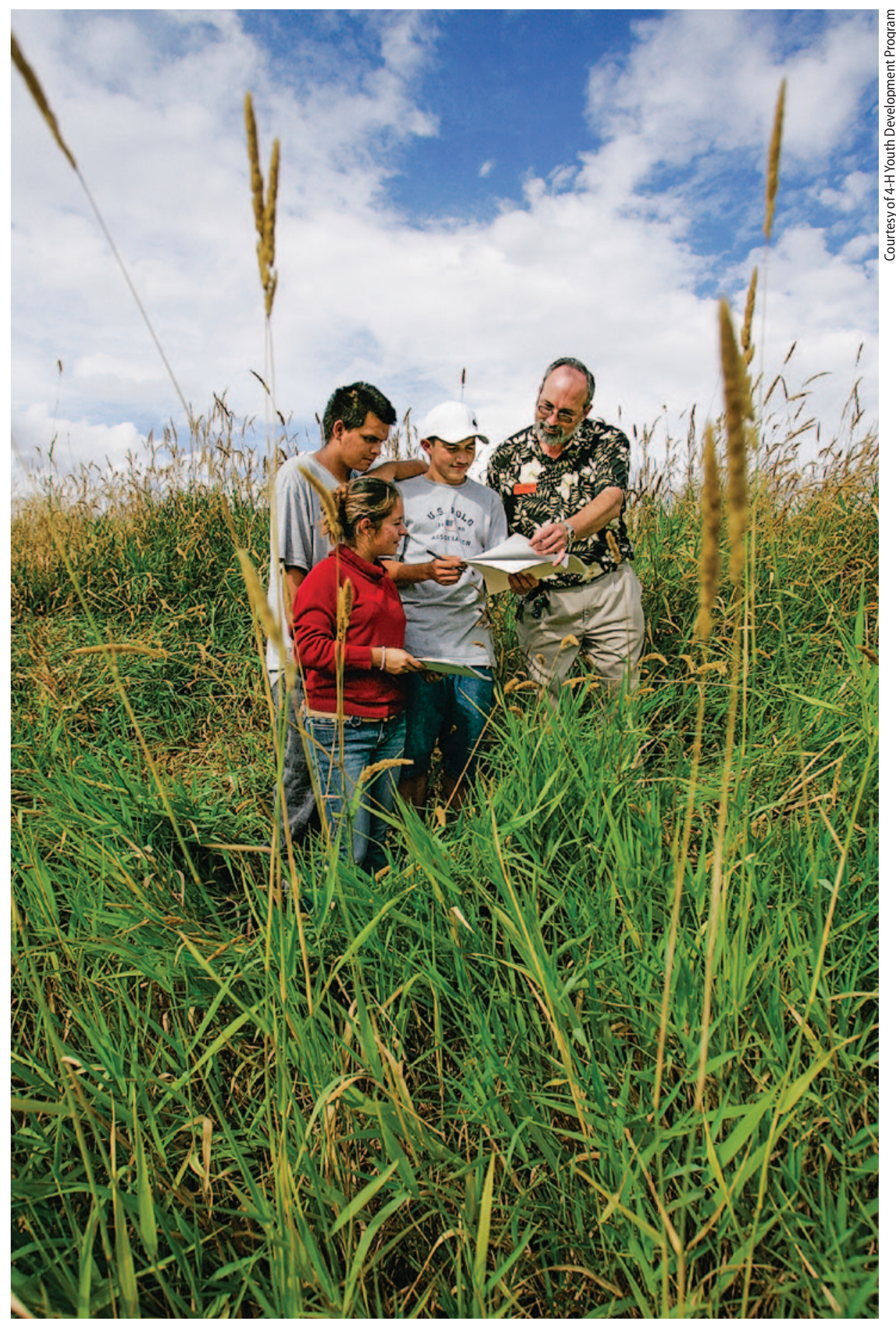

Increasing evidence suggests that out-of-school education may be more effective in improving scientific literacy than courses taught in school. Above, a 4-H volunteer uses content knowledge and teaching skills to facilitate a science activity in a natural setting. 
researchers as reform approaches to professional development, salient characteristics include:

- Extended duration.

- Active learning.

- Emphasis on pedagogical knowledge.

- Authentic context.

- Use of data.

- Connections to broader organizational and systemic efforts.

Duration. Professional development offered over an extended duration provides educators time to challenge their prior knowledge and beliefs by creating a high level of cognitive dissonance through discussions and review of literature (Loucks-Horsley et al. 2003; Supovitz and Turner 2000). By making sense of new information and experiences, educators can enhance their teaching practice and improve learner outcomes (Garet et al. 2001; Guskey and Yoon 2009; Loucks-Horsley et al. 2003; Supovitz and Turner 2000).

Active learning. Active learning allows participants to challenge prior ideas or understanding and make sense of new knowledge (Mestre 2005). Through active learning experiences such as observation, planning lessons or review of learners' work, educators are connected to their practice in the role of learners and are more likely to improve their knowledge and skills (Garet et al. 2001) and to have an investment in and ownership of their professional development (TorresGuzman and Hunt 2006).

Emphasis on pedagogical knowledge. According to Loucks-Horsley et al. (1998), "it is difficult if not impossible to teach in ways in which one has not learned," and without a transformation in the way science teachers are prepared, the use of strategies that emphasize direct instruction will continue. Additionally, in order to use constructivist-based teaching strategies effectively, educators must have multiple experiences with them as learners themselves (Dantonio and Beisenherz 2001). Thus, with the goal of improving scientific literacy among K-12 youth, it is imperative to build the pedagogical knowledge of science educators through ongoing professional development opportunities that model effective practices (Guskey and Yoon 2009; Loucks-Horsley et al. 2003).

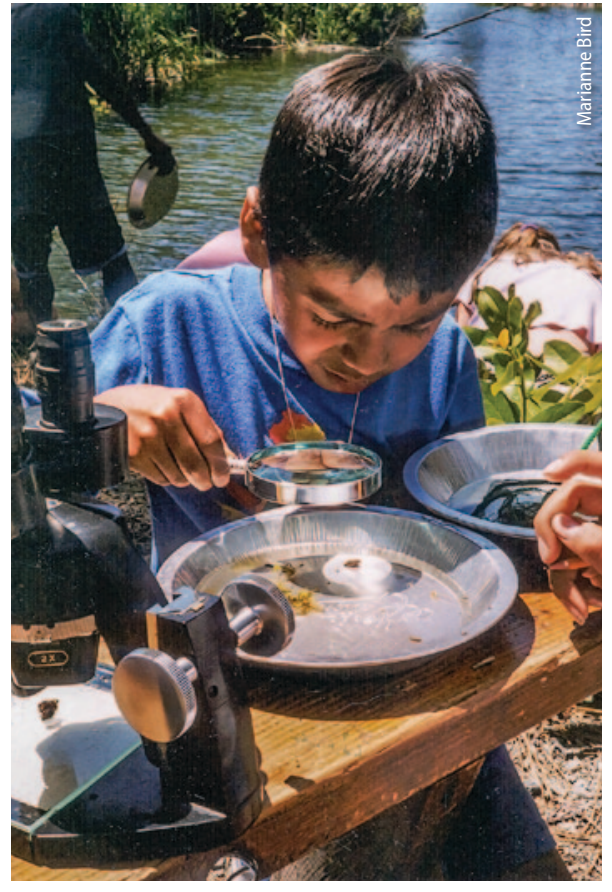

Nearly $50 \%$ of $4-\mathrm{H}$ members participate in hands-on science experiences. While continuing to offer agricultural science, 4-H curricula now include biological, environmental, engineering and technological sciences. Above, the Sacramento 4-H Environmental Education Camp.

Emphasis on subject matter knowledge. Another key to changing teaching practice in a manner that improves student learning is professional development that focuses on subject matter knowledge (Guskey and Yoon 2009; Loucks-Horsley et al. 2003; Penuel et al. 2007). Educators who are more competent in subject matter content are more disposed to encourage student questioning and discussion, essential features of the inquiry process (Penuel et al. 2007). Additionally, improvement of educators' science knowledge is critical because "science content increases and changes, and a teacher's understanding in science must keep pace" (National Research Council 1996).

Context. Professional development is most effective when it occurs within the context of authentic settings where educators work collaboratively to identify and address issues related to improving learner outcomes (Garet et al. 2001; Loucks-Horsley et al. 2003; Penuel et al. 2007; Supovitz and Turner 2000). When it occurs within authentic contexts, professional development has a closer "proximity to practice" and provides educators with greater opportunities to apply their learning directly to their educational settings (Penuel et al. 2007). Furthermore, Garet et al. (2001) maintained that professional development that occurs within the context of the education setting is more likely to be sustained over time.

Use of data. Guskey (2003) and LoucksHorsley et al. (2003) emphasized the importance of using authentic data from target audiences as a key component of effective professional development. The purpose behind this is to better connect the professional development process to learner outcomes - using learner data to help direct the process of advancing educators' practice - which is an additional, critical link to the emphasis on contextualization.-

Connections to broader efforts. Profes sional development efforts are more effective if they are part of an articulated program focused on advancing educators' knowledge and skills (Garet et al. 2001; Loucks-Horsley et al. 2003). This can be accomplished in a variety of ways, including linking professional development opportunities to broader goals and systemic efforts (e.g., science standards), aligning professional development with educators' needs and goals and including strategies that foster professional communication among participants (Garet et al. 2001; Loucks-Horsley et al. 2003; Supovitz and Turner 2000).

\section{Communities of practice}

Communities of practice (CoPs) represent one example of reform-based professional development. Specifically, CoPs are organized networks of peers within a profession and represent a model for situated professional development whereby groups of educators work toward shared learning goals that arise through authentic practice (Buysse et al. 2003). Communities of practice provide educators with a forum for reflection, and learning occurs "within the context of social relationships with other members of the community who have similar, if not identical, issues and concerns from the realm of practice" (Buysse et al. 2003). Participants co-construct knowledge within CoPs through social interactions; however, individuals enter into these communities on the periphery and, through time and the acquisition of knowledge and an understanding of the socio-cultural norms of the community, 
the level and complexity of their interactions increase (Lave and Wenger 1991; Wenger 1998). Mycue (2001) asserts that such group interactions among peers are essential for educator professional development, and Lambert et al. (2002) describe how CoPs advance not only the growth of educators but also the educational institution as a whole. Specific models of educator professional development that utilize CoPs include action research and lesson study.

Action research. Action research can be defined as "systematic, intentional inquiry" by educators into their own practice (Cochran-Smith and Lytle 1993). From a constructivist viewpoint, action research represents "inquiry as stance" (Cochran-Smith and Lytle 2001), whereby educators develop knowledge relative to their practice through direct experience. Furthermore, this reform model exhibits many of the characteristics of effective professional development outlined by Garet et al. (2001). Action research occurs within authentic contexts over an extended period of time, it links to broader goals and initiatives and fosters communication among participants, and it involves educators in active learning through which they challenge their existing ideas about teaching and learning and develop new knowledge that is data driven.

Procedurally, action research involves educators working collaboratively in a learning community to identify issues or concerns within their practice that focus on student learning and developing researchable questions around these topics. Using a systematic, intentional process that involves data collection, analysis and interpretation, the educators investigate these questions with the purpose of gaining new insights and understanding related to their teaching that will enhance students' learning. Mills (2003) summarizes the process by describing it as a 5-Step Action Research Cycle:

1. Select the area for investigation.

2. Collect data.

3. Organize data.

4. Analyze and interpret data.

5. Take action.

Once completed, the cycle can be repeated in successive iterations that address refined questions as a result of educators scaffolding their learning. Taken collectively, these steps set action research apart from traditional educational inquiry in that it is done "with" or "by" teachers rather than being done "on" or "to" them (Loucks-Horsley et al. 2003). Through action research, educators can "examine [their] practice, suggest changes in that practice, and assess the effects of those changes" (Lyle and Robinson 2002).

Lesson study. Lesson study is a form of action research that has gained increasing recognition in the United States (Lewis and Baker 2010). Jugyou kenkyuu, which translates into English as "lesson study" (Lewis, Perry and Murata 2006), has long been the main professional development model for teachers in Japan (Lewis, Perry, Hurd et al. 2006; Lewis, Perry and Murata 2006). Grounded in constructivist thinking, educators involved in the lesson study model work in teams to formulate goals, improve specific lessons within discrete contexts and explore deeper issues surrounding teaching and learning (Lewis 2009; Lewis et al. 2004; Lewis, Perry, Hurd et al. 2006; Lewis, Perry and Murata 2006; Rock and Wilson 2005).
The lesson study process is iterative and occurs over extended periods of time, often up to several years (Lewis, Perry and Murata 2006). By adopting an inquiry stance on their practice that involves the systematic collection, analysis and reporting of data, educators design, test and revise one or more lessons (Rock and Wilson 2005; Wiburg and Brown 2007). Integral to the lesson study process is "the belief that discussing others' points of view enhances the learning process and the final product" (Loucks-Horsley et al. 2003). Although relatively new to the United States (Wiburg and Brown 2007), lesson study has been shown to have positive effects on classroom educators' knowledge, skills and confidence (Rock and Wilson 2005; Wiburg and Brown 2007) and their abilities to design and teach science lessons (Marble 2006; Mutch-Jones et al. 2012).

\section{4-H volunteer development}

Volunteers are essential to the 4-H Youth Development Program, serving most commonly as nonformal educators who lead curriculum projects and

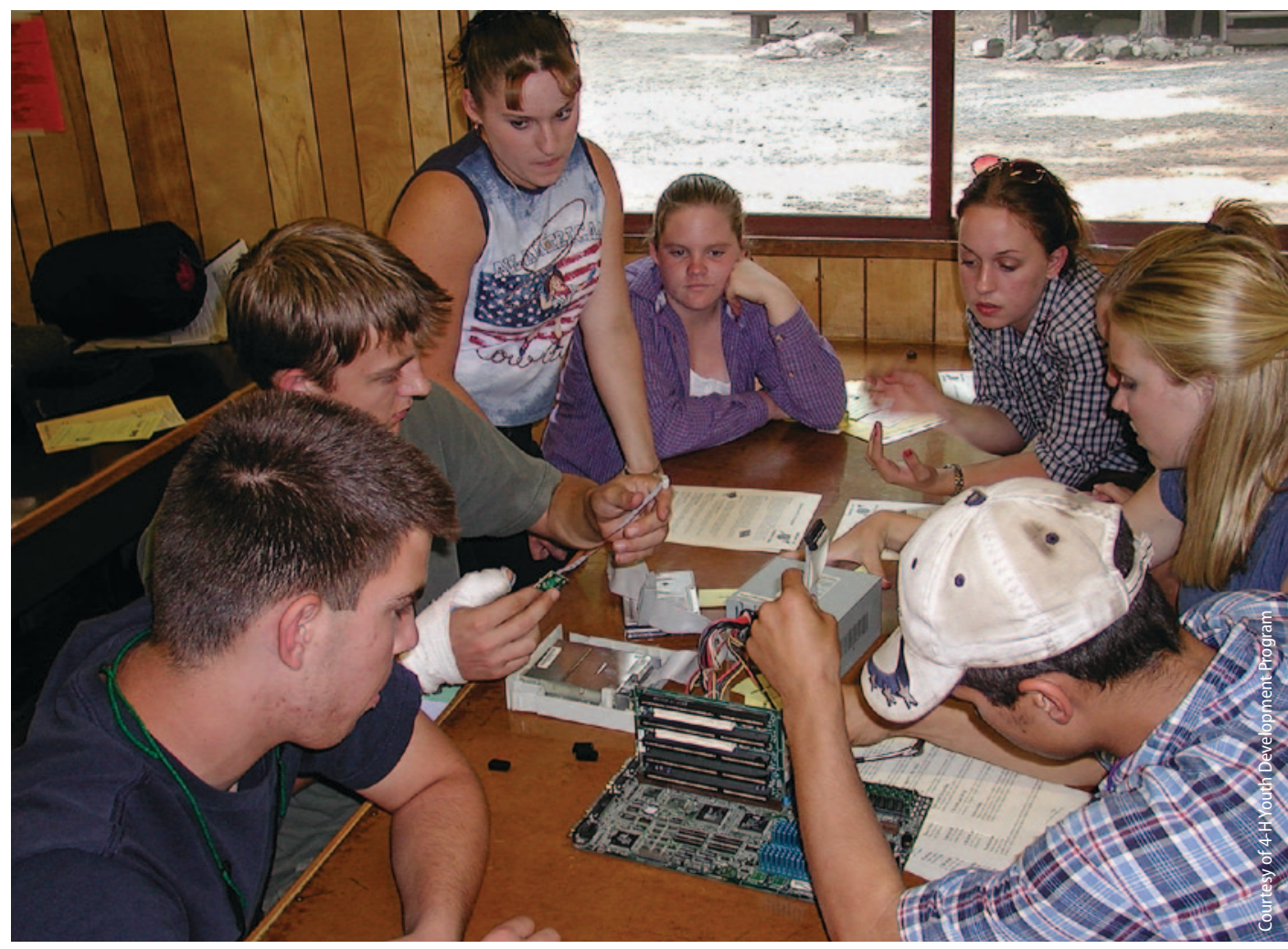

In a California survey of 4-H Youth Development advisors and program representatives (who train adult volunteers), $90 \%$ wished to explore the use of models like lesson study and action research as part of their county-based 4-H Science Engineering and Technology (SET) efforts. Shown is a 4-H technology leadership team presenting a workshop on computer hardware. 
activities with youth (Boyd 2004; Stedman and Rudd 2006). Approximately 414,000 adults are involved as $4-\mathrm{H}$ volunteers nationally each year (17,000 in California) (USDA 2010), and these individuals are commonly parents whose children are eligible to enroll in 4-H (Fritz et al. 2003). However, in order for $4-\mathrm{H}$ volunteers to be successful in their role as nonformal educators they must have access to and participate in effective professional development opportunities (Hoover and Connor 2001).

Effective professional development has been shown to improve volunteers' skills and confidence (Hoover and Connor 2001; Kaslon et al. 2005; Smith et al. 2005), increase the rate of volunteer retention (Van Winkle et al. 2002) and improve the sustainability of 4-H programs (Snider 1985). However, the most common approach to the professional development of 4-H volunteers has been through the use of traditional models such as one-time, face-to-face workshops of short duration that are led by Cooperative Extension personnel (Kaslon et al. 2005). For science education, professional development opportunities that are episodic in nature are considered ineffective (Garet et al. 2001; Guskey and Yoon 2009; Loucks-Horsley et al. 2003), and numerous sources have indicated a need to address the quantity, quality and design of professional development opportunities for 4-H volunteers in order to impact their ability to deliver nonformal science education programs effectively (e.g., Barker et al. 2009; Kaslon et al. 2005; Smith and Enfield 2002).

The investigation of reform-based professional development strategies rep-
(Junge et al. 2008). However, although some preliminary efforts to investigate the use of reform-based professional development strategies with program representatives and Youth Development advisors involved in science programming have occurred, only one study has been undertaken with $4-\mathrm{H}$ volunteers. In

\section{Effective professional development has been shown to improve volunteers' skills and confidence.}

resents an opportunity to help address the professional development needs of 4-H volunteers who implement SET programming with youth. In California, there is an interest among 4-H academic and program staff in exploring reformbased professional development models for use in 4-H SET programming. Survey results from an all-staff conference revealed that over $74 \%$ of California $4-\mathrm{H}$ Youth Development advisors and program representatives $(n=57)$ expressed a preference for professional development models like lesson study or action research, and over $90 \%(n=55)$ had an interest in exploring the possibility of using such strategies with volunteers as part of their county-based 4-H SET efforts

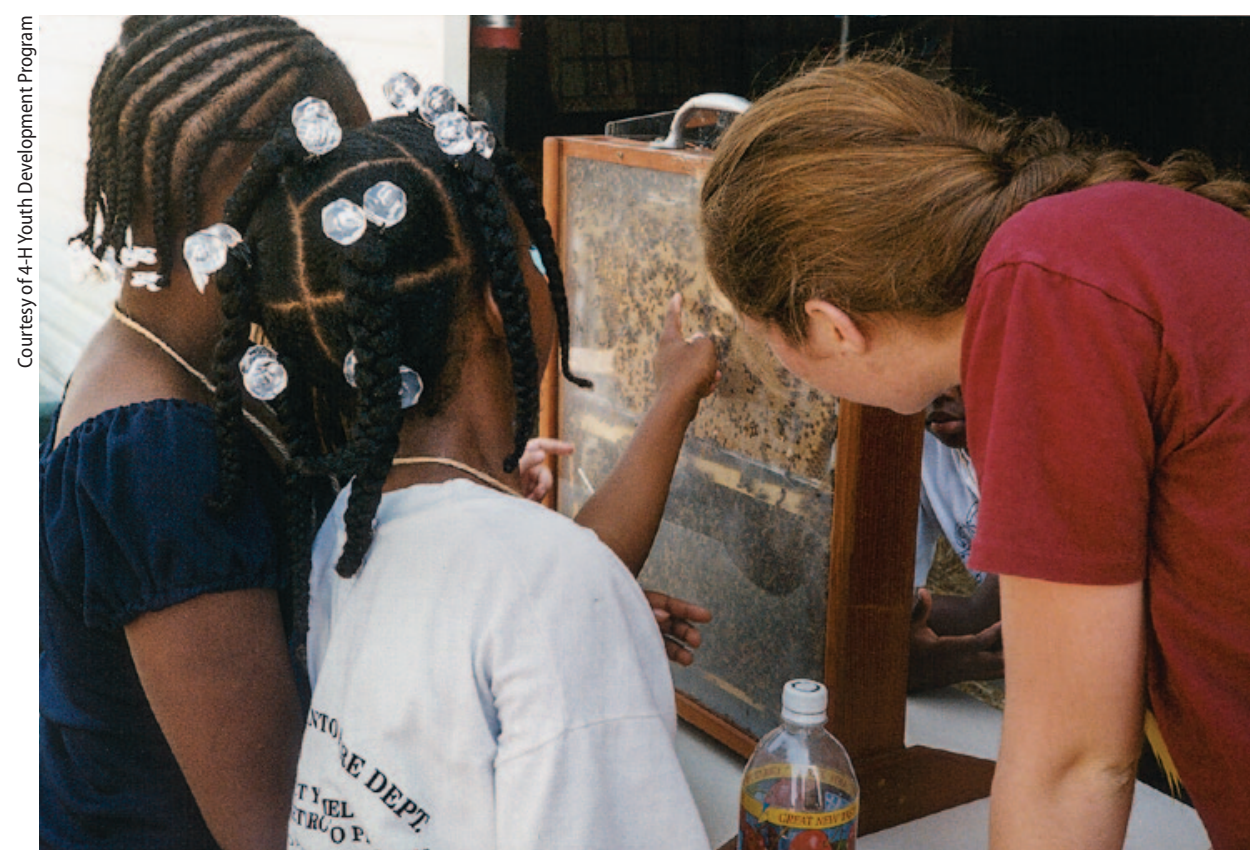

Participants in a 4-H Science, Engineering and Technology (SET) entomology project track the movements of bees in an observation hive. To enhance youths' learning, 4-H volunteers ask openended questions that promote inquiry.

this investigation, a sequential explanatory mixed-methods design was used to examine the influence of lesson study on 4 -H volunteers' understanding and use of inquiry methods and veterinary science content knowledge in three rural counties (see page 54). The results from this investigation were encouraging; however, no further testing on lesson study or other reform-based professional development models with 4-H volunteers has been done to date.

Improving the quality of professional development for 4-H volunteers who implement science programming with youth will require the careful investigation of new strategies such as action research and lesson study. However, this will take time and persistence and will require commitment from the individuals involved, as well as goals that are clearly defined by the organization (Loucks-Horsley et al. 2003). The motivation behind investigating reform methods of professional development in $4-\mathrm{H}$ is to improve $4-\mathrm{H}$ volunteers' abilities as science educators. The investment in developing a more competent cadre of volunteers will help strengthen 4-H SET programming and enhance the capacity of 4- $\mathrm{H}$ as an organization to have an impact on improving scientific literacy among California's youth population.

M.H. Smith is Cooperative Extension Associate Specialist, Youth Science Literacy, UC Davis; and L. Schmitt-McQuitty is 4-H Youth Development Advisor and UC Cooperative Extension County Director, San Benito County. 


\section{References}

[AAAS] American Association for the Advancement of Science. 1990. Science for All Americans. New York: Oxford University Press.

AAAS. 1993. Benchmarks for Science Literacy. New York: Oxford University Press.

Ambrose A, Mahacek RL, Schmitt-McQuitty L, et al. 2011. California 4-H Science, Engineering, and Technology (SET) Initiative Plan of Action (Revised). UC ANR. Unpublished document, UC Davis, CA.

Barker B, Grandgenett N, Nugent G. 2009. A new model of 4-H volunteer development in science, engineering and technology programs. J Extension (online) 47(2). Article 2IAW4. www.joe.org/joe/2009april/iw4.php. Bell P, Lewenstein B, Shouse A, Feder M (eds.). 2009. Learning Science in Informal Environments: People, Places, and Pursuits. Washington, DC: National Academies Press. $336 \mathrm{p}$

Bland J, Sherer D, Guha R, et al. 2011. The Status of the Teaching Profession 2011. Center for the Future of Teaching and Learning at WestEd. Sacramento, CA. Boyd BL. 2004. Extension agents as administrators of volunteers: Competencies needed for the future. J Extension 42(2).

Buysse V, Sparkman K, Wesley PW. 2003. Communities of practice in educational research: Connecting what we know with what we do. Except Children 69(3):263-77.

California State Board of Education. 1998. Science Content Standards for California Public Schools: Kindergarten Through Grade Twelve. www.cde.ca.gov/ $\mathrm{be} / \mathrm{st} / \mathrm{ss} /$ documents/sciencestnd.pdf.

Campbell D, Chen Z, Crawford P, et al. 2010. Healthy Families Communities Strategic Plan. Unpublished Document. UC ANR. http://ucanr.org/sites/HFC/ files/57631.pdf

Cochran-Smith M, Lytle SL (eds.). 1993. Inside/Outside: Teacher Research and Knowledge. New York: Teachers College Press.

Cochran-Smith M, Lytle SL. 2001. Beyond certainty: Taking an inquiry stance on practice. In: Lieberman A, Miller L (eds.). Teachers Caught in the Action: Professional Development That Matters. New York: Teachers College Press. p 45-58.

Cole DJ, Mahaffey G, Ramey L, et al. 2002. Preparing quality science educators: A successful tripartite partnership. Paper presented at Ann Meeting of Association of Teacher Educators, Feb 2, 2002. Denver, CO. ERIC Document Reproduction Service No. ED461658. Dantonio M, Beisenherz PC. 2001. Learning to Question, Questioning to Learn. Needham Heights, MA: Allyn \& Bacon.

Enfield RP. 2001, Winter. Connections between 4-H and John Dewey's philosophy of education. Focus. 4-H Center for Youth Development, Department of Human and Community Development, UC Davis.

Falk J, Dierking L. 2010. The 95 percent solution: School is not where most Americans learn most of their science. Am Sci 98(6):486-93.

Fritz S, Karmazin D, Barbuto J, Burrow S. 2003. Urban and rural 4-H adult volunteer leaders' preferred forms of recognition and motivation. J Extension 41(3).

Garet MS, Porter AC, Desimone L, et al. 2001. What make professional development effective? Results from a national sample of teachers. Am Educ Res J 38(4):915-45 Garrett B, Locklear E. 2007. 4-H Science, Engineering, \& Technology (SET). National 4-H Headquarters. USDA, Cooperative State Research, Education, and Extension Service. Washington, DC.

Grigg WS, Lauko MA, Brockway DM. 2006. The Nation's Report Card: Science 2005. National Center for Education Statistics, US Department of Education. Washington, DC. Guskey TR. 2003. Professional development that works: What makes professional development effective? Phi Delta Kappan 84(10):748-50.
Guskey TR, Yoon KS. 2009. What works in professional development? Phi Delta Kappan 90(7):495-500.

Hoover T, Connor NJ. 2001. Preferred learning styles of Florida association for family and community education volunteers: Implications for professional development. J Extension 39(3)

Jorgenson O, Vanosdall R. 2002. The death of science? What we risk in our rush toward standardized testing and the three R's. Phi Delta Kappan 83(8):601-5.

Junge S, Mahacek RL, Schmitt-McQuitty L, Smith MH. 2008. Survey Responses from the California 4-H Science, Engineering, and Technology Kick-Off Conference. September 2008. UC Davis, CA. Unpublished raw data. Junge S, Mahacek RL, Schmitt-McQuitty L, Smith MH. 2009. California 4-H Science, Engineering, and Technology (SET) Initiative Plan of Action. UC ANR. Unpublished document. UC Davis, CA.

Kahler J, Valentine N. 2011. Stemming the gap. Educ Digest 76(6):54-5.

Kaslon L, Lodl K, Greve V. 2005. Online leader training for 4-H volunteers: A case study of action research. J Extension 43(2)

Lambert L, Walker D, Zimmerman DP, et al. 2002. The Constructivist Leader (2nd ed.). New York: Teachers College Press.

Lappan G. 2000. A vision of learning to teach for the $21 \mathrm{st}$ century. School Sci Math 100(6):319-26.

Lave J, Wenger E. 1991. Situated Learning: Legitimate Peripheral Participation. Cambridge, UK: Cambridge University Press.

Lewis C. 2009. What is the nature of knowledge development in lesson study? Education Action Research 17(1):95-110.

Lewis C, Baker E. 2010. Action research through the lens of lesson study. In: Pelton R (ed.). Action Research for Teacher Candidates: Using Classroom Data to Enhance Instruction. Lanham, MD: Rowan \& Littlefield.

Lewis C, Perry R, Hurd J. 2004. A deeper look at lesson study. Educ Leadership 61(5):18-23.

Lewis C, Perry R, Hurd J, O'Connell MP. 2006. Lesson study comes of age in North America. Phi Delta Kappan 88(4):273-81.

Lewis C, Perry R, Murata A. 2006. How should research contribute to instructional improvement? The case of lesson study. Educ Researcher 35(3):3-14.

Loucks-Horsley S, Hewson P, Love N, Stiles K. 1998. Designing Professional Development for Teachers of Science and Mathematics. Thousand Oaks, CA: Corwin Press.

Loucks-Horsley S, Love N, Stiles K, et al. 2003. Designing Professional Development for Teachers of Science and Mathematics (2nd ed.). Thousand Oaks, CA: Corwin Press. Lyle KS, Robinson WR. 2002. An action research report: Improving pre-laboratory preparation of first-year university students. J Chem Educ 79(6):663-5.

Marble ST. 2006. Learning to teach through lesson study. Action Teach Educ 28(3):86-96.

Mestre JP. 2005, Winter. Facts and myths about pedagogies of engagement in science learning. Peer Review 24-7.

Miller J. 2006. Civic scientific literacy in Europe and the United States. Paper presented at Ann Conf of World

Assoc for Public Opinion Res, May 17, 2006. Montreal, Canada.

Mills GE. 2003. Action Research (2nd ed.). Upper Saddle River, NJ: Pearson.

Minner DD, Levy AJ, Century J. 2010. Inquiry-based science instruction - What is it and does it matter? Results from a research synthesis years 1984 to 2002. J Res Sci Teach 47(4):474-96.

Mørch S, du Bois-Reymond M. 2006. Young Europeans in a changing world. New Dir Child Adolescent Dev 113:23-35. doi: 10.1002/cad.
Mutch-Jones K, Puttick G, Minner D. 2012. Lesson study for accessible science: Building expertise to improve practice in inclusive science classrooms. J Res Sci Teach 49(8):1012-34

Mycue S. 2001. The professional circle. Kappa Delta Pi Record 38(1):28-31.

National Research Council. 1996. National Science Education Standards: Observe, Interact, Change, Learn. Washington, DC: National Academies Press. www.archive. org/details/nationalsciencee00natirich.

National Research Council. 2007. Rising above the Gathering Storm: Energizing and Employing America for a Brighter Economic Future. Washington, DC: National Academies Press.

[NCES] National Center for Education Statistics. 2011. The Nation's Report Card: Science 2009. NCES 2011451. Institute of Education Sciences, US Department of Education. Washington, DC. http://nces.ed.gov/ nationsreportcard/pdf/main2009/2011451.pdf.

Penuel WR, Fishman BJ, Yamaguchi R, Gallagher LP. 2007. What makes professional development effective? Strategies that foster curriculum implementation. Am Educ Res J 44(4):921-58.

Regents of UC. 2009. University of California Division of Agriculture and Natural Resources Strategic Vision 2025 http://ucanr.org/files/906.pdf.

Rock TC, Wilson C. 2005. Improving teaching through lesson study. Teach Educ Quart 32(1):77-92.

Schwerdt G, Wuppermann A. 2011. Sage on the stage. Educ Next 11(3). http://educationnext.org/sageon-the-stage.

Smith MH, Dasher HS, Klingborg DJ. 2005. A model for recruiting and training youth development volunteers in urban areas. J Extension 43(5)

Smith MH, Enfield RP. 2002. Training 4-H teen facilitators in inquiry-based science methods: The evaluation of a "step-up" incremental training model. J Extension (online) 40(6). www.joe.org/joe/2002december/a3.shtml.

Smith MH, Trexler CJ. 2006. A university-school partnership model: Providing stakeholders with benefits to enhance science literacy. Action Teach Educ 27(4):23-34

Snider A. 1985. The dynamic tension: Professionals and volunteers. J Extension 23(3).

Stedman NLP, Rudd R. 2006. Leadership styles and volunteer administration competence: Perceptions of 4-H county faculty in the United States. J Extension 44(1).

Sullenger K. 2006. Beyond school walls: Informal education and the culture of science. Educ Canada 46(3):15-8.

Supovitz JA, Turner HM. 2000. The effects of professional development on science teaching practices and classroom culture. J Res Sci Teach 37(9):963-80.

Torres-Guzman ME, Hunt V. 2006. Teacher study groups: In search of teaching freedom. New Educ 2:207-26.

[USDA] United States Department of Agriculture. 2010. 4-H Reports: Research, Education \& Economics Information System. www.reeis.usda.gov/portal/ page? pageid $=193,899783 \&$ dad $=$ portal $\&$ schema=PORTAL\&smi_id =31.

Van Winkle R, Busler S, Bowman S, Manoogian M. 2002. Adult volunteer development: Addressing the effectiveness of training new 4-H leaders. J Extension 40(6)

Wenger E. 1998. Communities of Practice: Learning, Meaning, and Identity. New York: Cambridge University Press

Wiburg K, Brown S. 2007. Lesson Study Communities. Thousand Oaks, CA: Corwin Press. 